\title{
"Det er blevet et socialt netværk" - forbedring af studiemiljøet gennem studiefacilitering
}

\author{
Hanne Kirstine Adriansen, ph.d., lektor, Institut for Uddannelse og Padagogik, \\ Aarhus Universitet, hkoa@dpu.dk. \\ Ib Ravn, ph.d., lektor, Institut for Uddannelse og Padagogik, Aarhus Universitet, \\ ibr@dpu.dk.
}

\section{Reviewet artikel}

Vi søgte at forbedre studiemiljøet på DPU ved at styrke samarbejdet $i$ studiegrupperne. Til det formål trænede vi 17 studerende i facilitering. Disse studiefacilitatorer styrede derefter interaktion og peer learning $i$ deres studiegrupper. Virkningen på studiemiljøet var god; bl.a. tredobledes andelen af studerende, der følte sig som del af et større frllesskab på studiet. Omkring 500 nye studerende trænes hvert år i facilitering af studiegrupper på DPUs to største kandidatuddannelser.

\section{Introduktion}

I foråret 2008 publicerede Aarhus Universitet en undersøgelse af studiemiljø og trivsel blandt de studerende (AU, 2008a). Den viste, at de studerende generelt var tilfredse med deres studier, men et af de daværende syv fakulteter stak ud. Vores arbejdsplads, det daværende DPU (nu Institut for Uddannelse og Pædagogik), havde et markant dårligere studiemiljø.

Alle DPUs studerende var på undersøgelsestidspunktet kandidatstuderende. De fleste havde en professionsbachelor og nogle års erfaring som fx lærer, pædagog eller sygeplejerske. De var i gennemsnit 10 år ældre end de øvrige AU-studerende, og en del var reelt deltidsstuderende. Mange havde familie og børn og lang transporttid til universitetet (AU, 2008b). En stor del af undervisningen foregår som forelæsninger (resten er VIP-undervist holdundervisning), og undervisningen er koncentreret til to dage om ugen. Disse forhold kan være nogle af forklaringerne på den lavere trivsel på DPU sammenlignet med de andre fakulteter.

Gennem vores forskning i videndeling og mødeledelse (bl.a. Elsborg \& Ravn, 2006; Ravn, 2007) havde vi erfaring med, at samarbejdet på møder og konferencer og i net- 
værk kan gøres engagerende, nærværende og udbytterigt ved brug af facilitering. Med resultaterne fra studiemiljøundersøgelsen på AU var det oplagt at stille spørgsmålet: Ringe fagligt fællesskab, ensomhed på studiet, dårlig kontakt til medstuderende - var det områder, man kunne forbedre ved at facilitere de studerendes samvær i studiegrupper og på campus generelt?

Vi skitserede et projekt, hvor vi gennem faciliterede processer ville fremme et studiemiljø, der skulle øge de studerendes faglige udbytte, uddybe deres tilknytning til hinanden og til DPU samt skærpe deres professionelle identitet. Det stod klart, at der var aspekter ved den ringe studietrivsel, som faciliterede processer ikke kunne hjælpe på, bl.a. undervisningens kvalitet og organisering, manglende feedback fra undervisere og manglende gennemsigtighed i faglige krav. Men samværet i studiegrupper og på campus måtte kunne tackles gennem facilitering.

I denne artikel analyserer vi projektet, hvis resultater peger på, at man kan forbedre studiemiljøet ved hjælp af facilitering.

\section{Facilitering: Hinsides autoritær og spontan orden}

Facilitering er et redskab, hvormed en leder eller ordstyrer kan gøre det lettere for en forsamlet gruppe mennesker at udrette det, de vil (facilis: lat. let at gøre). Som facilitator søger man at hjælpe gruppen med at samtale og vekselvirke mere hensigtsmæssigt, end de kan ufaciliteret.

Facilitator udsteder venlige opfordringer og vejledende spørgsmål til sine mødedeltagere. For eksempel: "Mona, må jeg holde dig tilbage, til vi har hørt fra de andre?" og "Må jeg bede jer gå sammen to og to og drøfte spørgsmålet i 10 minutter?" Deltagerne efterkommer disse opfordringer, så længe de opfatter facilitator som legitim, dvs. har tillid til at hun hjælper dem med at nå deres mål.

I facilitering er sondringen mellem indhold og proces central. "Facilitation is about process - how you do something - rather than content - what you do" (Hunter, 2009: 17). Når man faciliterer, bidrager man til at skabe social orden, typisk i den lille gruppe, men med konsekvenser for den sociale orden i større kontekster fx organisationer og uddannelsesinstitutioner.

To brede opfattelser af social ordensskabelse har præget den samfundsvidenskabelige tænkning det sidste halve århundrede:

1. Dels forestillingen om orden som villet eller beordret oppefra og udefra, som $\mathrm{fx}$ autoritær ledelse, der skaber orden gennem ordrer, eller iflg. "rational actor"modellen (Allison, 1971), hvor ledere i kraft af planlægning og beslutningstagning kan skabe en ønsket organisationsform (Ansoff, 1979). 
2. Dels forestillingen om social orden som spontant opstået indefra eller nedefra, blandt aktører i institutioner (Berger og Luckmann, 1966), personer i samtale (Mead, 1934), ansatte i organisationer (Stacey, 2003) eller professionelle i relationer (Gergen, 2005). I dette perspektiv ses den type orden, der søges skabt udefra, som noget mangelfuldt og ikke eftertragtelsesværdigt, og forskere som de nævnte sætter generelt deres lid til selvorganisering og spontant frembrydende sociale former.

Set i lyset af disse to perspektiver er møder og gruppearbejder i Danmark havnet i et dilemma: De færreste ønsker den autoritære form, mens det modsatte, det mere spontane samvær, har medført en udbredt "snakkekultur", hvor ingen føler sig berettiget til at holde diskussionen fokuseret og sikre et resultat af mødet.

Facilitering kan forstås som et redskab, hvormed man kan overskride denne dikotomi mellem påtvunget ydre og spontant opstået, indre social orden (Ravn, 2011, kap. 7 og 10). En facilitator er ydre i den forstand, at hun faciliterer menneskers samvær efter en plan, som hun mener, vil give gruppen et bedre resultat, end hvis den skulle klare sig selv. Og hun repræsenterer gruppens indre orden, for så vidt som hun beder deltagerne samtale og vekselvirke på måder, der tilgodeser deres egne behov for involverende og resultatskabende gruppesamvær.

Hvad angår studiemiljøet på uddannelsesinstitutioner ligger udfordringen i at facilitere de studerendes samvær både stramt $o g$ blidt - sådan at gruppen både gør seriøse læringsmæssige fremskridt og oplever en opblomstring af tillid og socialt samvær.

\section{Projektforløb: Studiegrupper og studiebar}

Finansieret af en intern særbevilling iværksatte vi i januar 2009 projektet med 222 studerende på 2. semester af kandidatuddannelsen i Pædagogisk Psykologi. Det er den største af DPUs uddannelser med et optag på ca. 200 i København og 100 i Århus. Projektet bestod af tre dele: Faciliterede studiegrupper, faciliteret studiebar og faciliterede temadage om faglig identitet.

\section{Delprojekt 1: Facilitering af studiegrupper}

Traditionelt er de studerende blevet opfordret til at danne studiegrupper. Ideen med dette delprojekt var, at én studerende i hver studiegruppe skulle fungere som gruppens facilitator ved at igangsætte processer til peer learning og videndeling i gruppen. Vi bygger på Bouds forståelse af peer learning som gensidig læring (Boud, 2001). Når der som i nærværende projekt indføres en facilitator, sikres det, at én har ansvaret for at guide gruppen mod dens mål ved at holde diskussioner på sporet og høre alle. Studiegrupperne havde til formål at bearbejde pensum som en støtte til forelæsningerne. De var ikke projektgrupper, der skulle skrive opgaver sammen. Vi 
kaldte dem kollegiale fællesskaber, hvor deltagerne skulle inspirere hinandens læring.

Ved at udsende en mail til samtlige studerende på årgangen rekrutterede vi 17 kommende facilitatorer. De deltog i en todages workshop i studiefacilitering afholdt som internat ved begyndelsen af semestret.

For at kickstarte projektet deltog vi desuden i semestrets introdage. Sammen med modulkoordinatorerne Eva Silberschmidt Viala og Lisser Rye Ejersbo orienterede vi de studerende om projektet, demonstrerede en håndfuld faciliterede processer med dem og hjalp dem med at danne studiegrupper på stedet.

Til de efterfølgende, ca. ugentlige studiegruppemøder guidede facilitator gruppen gennem forskellige processer mhp. at bearbejde en eller flere af teksterne til den kommende forelæsning. De en-times møder bestod eksempelvis af en tavs refleksion over et spørgsmål (5 min), summe-med-sidemand (15 min), en lynrunde hvor alle kommer på, fri snak i plenum (20 min), afsluttet med en refleksion over "Hvad tager du med dig fra i dag?" (5 min). Dermed fik alle en mulighed for at reflektere over og diskutere teksten, uden at nogle få, meget talende, dominerede.

Til disse processer kræves flere deltagere end den sædvanlige studiegruppes 4-6 medlemmer. De faciliterede studiegrupper fik hver 11-14 deltagere, hvilket er en god størrelse at facilitere. Det gjorde også grupperne robuste over for fravær og frafald og gav en større social tyngde og mangfoldighed.

De igangsættende spørgsmål, som facilitator formulerede, var enten "akademiske" eller "erfaringsorienterede". Akademiske spørgsmål adresserer teksten på dens egne præmisser, fx "Hvad er argumentet i teksten?" og “Hvordan er de to begreber forskellige?". Erfaringsorienterede spørgsmål søger at knytte en forbindelse mellem teksterne og de studerendes personlige og professionelle erfaringer, fx "Hvad var tekstens vigtigste pointe for dig?" og "Hvordan kan du bruge begreberne i dit praktiske arbejde?" Med spørgsmål af begge typer søger man at øge både forståelsen af pensum og dets relevans for den enkelte.

Nogle grupper mødtes også socialt; og nogle fortsatte efter semesterafslutning. Foruden det ugentlige gruppemøde blev grupperne brugt, når forelæserne iværksatte et gruppearbejde på fx en halv time undervejs i de typisk seks timer lange forelæsningsdage. Dette bevirkede, at de studerende med det samme vidste, hvem de skulle være sammen med, og at der var en facilitator i hver gruppe, der tog ansvar for processen.

Selv om disse faciliterede studiegrupper er store, skal de ikke forveksles med holdundervisning, øvelser eller seminarer. Der finder ikke undervisning sted, og ingen 
VIP'er, instruktorer eller ældre studerende er nødvendige. Studiefacilitatoren er ikke indholdsleverandør; hun er ikke klogere på pensum end de andre gruppedeltagere. Men hun er klogere på form, og hun styrer gruppens samtaleprocesser på en sådan måde, at hver deltager får bidraget med sit indhold til fælles læring. Faciliterede studiegrupper er et alternativ til ustyrede, ufokuserede studiegrupper, ikke til undervisning.

\section{Delprojekt 2: Faciliteret studiebar}

Studiebarer er ikke noget nyt, men en faciliteret bar er. Her er ideen, at man sagtens kan komme alene, for man kommer ikke til at stå alene, men lærer hurtigt nogle at kende. Faciliterede processer sikrer, at alle hurtigt lærer nogle at kende - og der blev snakket både fagligt og socialt. Et typisk forløb var: Velkomst. 15 minutter hvor alle blev bedt om at hilse på 10-15 andre, gående rundt i baren. 45 minutters fordybelse i trepersoners grupper om store, gode oplevelser på studiet. Lang pause med chips og en øl. 45 minutters opdagelsesrejse i skiftende par: "Find den mest sjældne ting, I to har til fælles". Lidt at spise og en times fri snak og mingling.

Vi arrangerede faciliteret studiebar tre gange i København og to i Aarhus med lidt hjælp fra enkelte facilitatorer. Arrangementerne lå i umiddelbar forlængelse af undervisningen, sidst på eftermiddagen - godt for DPUs studerende med lang transporttid.

\section{Delprojekt 3: Temadag om faglig identitet}

Hensigten med dette lille delprojekt var at styrke de studerendes faglige identitet, som ifølge studiemiljøundersøgelsen er ringe. Mange studerende oplever, at de giver slip på en velkendt professionel identitet som fx lærer eller pædagog uden at få en ny, idet Pædagogisk Psykologi er en ny og forholdsvis ukendt uddannelse. Vi stod for arrangementet uden hjælp fra facilitatorerne. I løbet af en halv dag med faciliterede aktiviteter diskuterede de studerende deres faglige ambitioner og identitet.

\section{Evaluering}

Ved afslutningen af semestret evaluerede vi de tre delprojekter vha. spørgeskema og interview. Spørgeskemaet indeholdt to dele: 19 spørgsmål om deltagelse i og udbytte af de tre delprojekter (heraf var fire spørgsmål åbne, fire var kvantitative på en Likert femtrinsskala, og resten var kategoriale: om fraværsårsager osv.) samt 9 spørgsmål fra AU's studiemiljøundersøgelse (AU, 2008b). Det blev uddelt ved semestrets sidste forelæsning; svarprocenten var derfor lig fremmødet, hvilket var $70 \%$.

Til uddybning af det kvantitative spørgeskema interviewede vi ikke de studerende, men studiefacilitatorerne. Vores erfaring siger os, at facilitering er som rengøring: Man opdager den kun, hvor den mangler. Personer, der faciliteres godt, oplever ikke formen, som facilitator er ansvarlig for. Et mere analytisk blik forudsætter kyndighed 
i facilitering. Facilitatorerne kunne derfor give os en kvalificeret forståelse af spørgeskemaets resultater. Blandt de 17 studiefacilitatorer blev dem i København interviewet individuelt og dem i Århus som fokusgruppe. Interviewene blev foretaget af den ene af os (Adriansen) samt lektor Lene Møller Madsen fra Københavns Universitet, som sammen også har foretaget observationer af studiegrupperne. Evalueringen og yderligere beskrivelse af projektet kan findes i Ravn og Adriansen (2009) samt i Adriansen og Madsen (2012).

\section{Analyse}

Fra AUs studiemiljøundersøgelse udvalgte vi 9 spørgsmål om forhold, som vi forventede at kunne påvirke gennem projektet. De ses i tabel 1. Kolonnen længst til højre er data fra vores spørgeskema, mens de tre kolonner til venstre herfor er fra AUs undersøgelse (2008a, 2008b). Bemærk at der er tale om to forskellige populationer: I AUs undersøgelse gennemført i 2007 blev alle studerende på AU inviteret til at svare. En delmængde heraf er tallene fra DPU (kolonne 2), og en delmængde heraf igen er tallene på DPU's kandidatuddannelse i Pædagogisk Psykologi (kolonne 3). I kolonne 4 er det 2. semesterstuderende på Pædagogisk Psykologi i 2009. Hermed søger vi, at anslå virkningen af projektet. Signifikansværdier kan i sagens natur ikke beregnes, og sammenligninger kan kun foretages med forbehold.

Tabel 1. Resultater fra studiemiljøundersøgelsen på Aarhus Universitet og efter projektet $i$ studiefacilitering på kandidatuddannelsen i Pædagogisk Psykologi.

\begin{tabular}{|c|l|c|c|c|c|}
\hline & $\begin{array}{l}\text { Andel studerende, der svarer "overvejende enig" eller "helt enig” på } \\
\text { flg. spørgsmål: }\end{array}$ & $\begin{array}{l}\text { AU } \\
\text { (a) }\end{array}$ & $\begin{array}{l}\text { DPU } \\
\text { (b) }\end{array}$ & $\begin{array}{l}\text { PP } \\
\text { (c) }\end{array}$ & $\begin{array}{l}\text { Projekt } \\
\text { (d) }\end{array}$ \\
\hline 1 & Jeg føler mig som en del af et større fællesskab på studiet & 55 & 24 & 21 & 60 \\
\hline 2 & $\begin{array}{l}\text { Hvordan vurderer du mulighederne for social kontakt med medstu- } \\
\text { derende? }\end{array}$ & 72 & 32 & 29 & 74 \\
\hline 3 & $\begin{array}{l}\text { Studiet har bidraget til, at jeg føler mig som del af et fagligt fælles- } \\
\text { skab }\end{array}$ & 74 & 54 & 48 & 70 \\
\hline 4 & \begin{tabular}{l} 
Jeg føler mig generelt rigtig godt tilpas på mit studium \\
\hline 5
\end{tabular} & 83 & 69 & 67 & 84 \\
\hline 6 & $\begin{array}{l}\text { De andre studerende er generelt } \\
\text { imødekommende }\end{array}$ & 78 & 80 & 91 \\
\hline Hvor ofte føler du dig ensom - & 9 & 16 & 19 & 8 \\
\hline 8 & $\begin{array}{l}\text { Hvor ofte føler du dig ensom - } \\
\text { til daglig uden for studiet? }\end{array}$ & 5 & 5 & 8 \\
\hline 8 & $\begin{array}{l}\text { Min interesse i studiets fagområde er vokset, siden jeg startede på } \\
\text { studiet }\end{array}$ & 85 & 88 & 90 & 90 \\
\hline 9 & $\begin{array}{l}\text { Studiet har bidraget til at afklare, hvilket arbejde jeg vil have, når jeg } \\
\text { er færdig }\end{array}$ & 43 & 33 & 32 & 32 \\
\hline
\end{tabular}

(a) Aarhus Universitet, $\mathrm{n}=8469$, svarprocent $28,5 \%$ (fra AU, 2008a).

(b) DPU, n=630, svarprocent 19,7 \% (fra AU, 2008b).

(c) Kandidatuddannelsen i Pædagogisk Psykologi, n=192, svarprocent 22,1 \% (fra AU, 2008b).

(d) Efter projekt om studiefacilitering, n=156, svarprocent 70,3 \% (fra spørgeskema). 
Hvis vi ser nærmere på tallene fra Pædagogisk Psykologi før faciliteringsprojektet (dvs. søjle PP), viser tabellen, at de studerende var vældig interesserede i studiets fagområde ( $90 \%$, se nr. 8), men at dette ikke betød, at man ikke automatisk følte sig som en del af et fagligt frellesskab, hvilket kun 48 \% gjorde (nr. 3).

Hele $80 \%$ af de studerende oplevede, at de andre studerende var imødekommende (nr. 5), men deraf følger åbenbart ikke, at der er gode muligheder for at komme i social kontakt med dem, hvad kun $29 \%$ oplevede (nr. 2). Dette er formentlig en medvirkende årsag til, at kun de færreste føler sig som en del af et større fællesskab på studiet, nemlig $21 \%$ (nr. 1), og at der er en relativt stor andel, der føler sig ensomme på studiet til daglig, nemlig $19 \%, \bmod 9 \%$ på resten af AU (nr. 6).

Tabellen viser også, at det med faciliteringsprojektet lykkedes at forbedre nogle af de meget dårlige trivselsscorer på Pædagogisk Psykologi (søjle Projekt) (idet ingen andre forhold antages at have påvirket netop dette semester differentielt). De syv første gik op:

Det faglige fxllesskab steg fra $48 \%$ til $70 \%$ (nr. 3). Det blev formentlig stimuleret af bearbejdningen af det faglige stof i de faciliterede studiegrupper. En facilitator forklarer (alle de følgende citater er fra interview med facilitatorerne):

"I og med, at det ikke blev 'Hvem ved mest om Bourdieu?', så turde man også melde på. Og dét at få det forankret $i$ sin praksis gjorde også, at folk kom til at føle, at de kunne noget og på den måde turde diskutere mere og blande sig mere."

Et fagligt fællesskab ligger bl.a. i at have nogen at drøfte faglige emner med på en tryg og stimulerende måde. Også den almene (ikke decideret faglige) fællesskabsoplevelse steg markant, fra $21 \%$ til $60 \%$ (nr. 1), ligesom flere følte sig godt tilpas på studiet og langt færre følte sig ensomme.

Som nævnt har der før været studiegrupper på DPU, men som så mange andre steder var erfaringerne blandede. Efter at have arbejdet i en faciliteret studiegruppe siger en studerende ifølge facilitator:

"Hvor er det rart, at der er en, der styrer tiden."

Facilitators igangsættende spørgsmål. Mange studerende taler om betydningen af at bruge spørgsmål som en måde at strukturere diskussionen i studiegruppen på. Specielt var de erfaringsorienterede spørgsmål gode, idet de gjorde det muligt for de studerende at oversætte fra teori til praksis og forbinde litteraturen med deres professionelle erfaringer. Dette beskrives af en facilitator som "forankring":

"Det har haft stor betydning for dem, at de har kunnet forankre det, og at det var tilladt her." 
Faciliteringen i kombination med de forskellige spørgsmålstyper betød også, at flere deltog aktivt i gruppearbejdet. Dette var tydeligt under vores observationer af studiegrupperne, og en af facilitatorerne fortalte:

"Der var flere, der sagde: 'Jeg tør aldrig sige noget $i$ sådan nogle grupper her', og at det havde været behageligt, og at man havde syntes, at man bød ind med noget, og at det kan ligge i faciliteringen."

Studiemiljøet generelt blev stimuleret både i kraft af studiegrupperne og af den faciliterede bar. De studerende har altid oplevet hinanden som imødekommende (80\% før, $90 \%$ efter projektet), men rare enkeltpersoner giver ikke i sig selv et rart miljø. Det skal faciliteres, som denne studerende siger:

"Det er som om, at der skal sættes nogle rammer, før folk kommer ... Fordi i virkeligheden gider vi jo godt hinanden."

En facilitator sammenfatter sine medstuderendes afsluttende evaluering fra en studiegruppe således:

"De siger, det er blevet et socialt netværk. At studiet er blevet anderledes. Der er flere at henvende sig til. Man snakker med nogen, når man står $i$ kø. Man synes, man hører til. Man smiler, når man kommer ind. Man ved, hoad folk hedder."

Det lader til, at de faciliterede studiegrupper har øget interaktionen blandt de studerende, og at dette i kombination med den faciliterede studiebar har ledt til den konstaterede stigning i fællesskabsoplevelsen. Vi anser derfor interaktion for at være en væsentlig årsag til projektets succes. De studerende formår tilsyneladende ikke selv at skabe den nødvendige interaktion; den skal faciliteres, og gerne i en faglig kontekst.

\section{Facilitering som middel til faglig og social interaktion}

Resultaterne fra projektet i studiefacilitering peger på, at rollen som facilitator kan være meget nyttig, når den faglige videndeling og det sociale samvær skal forløbe bedre og gå op i en højere enhed. Danske uddannelsesinstitutioner har gennem fyrre års oprør mod autoriteter vaccineret sig selv mod stram styring oppefra og er visse steder gået i den modsatte grøft, bl.a. i studiegrupper, hvor ingen må styre og diskussioner bevæger sig frit ud ad tangenter.

En tredje vej hinsides autoritær styring og komplet gruppespontanitet søgte vi at skabe ved at træne studerende $\mathrm{i}$ at facilitere hinanden, dvs. midlertidigt påtage sig rollen som den, der på gruppens vegne søger at holde fokus og retning, så alle får et fagligt udbytte af samtalen, ikke kun den mindre del, der altid træder frem og dominerer diskussioner. Når en facilitator blidt men bestemt guider samtalen, så alle får 
lejlighed til at bidrage, øges fortrolighed og tillid i gruppen hurtigere og mere effektivt, end når man skal vente på, at de gode og berigende samtaler opstår af sig selv. Heri lægger studiefacilitering sig op ad andre tiltag til gruppeledelse (fx rød og grøn projektleder, Darsø og Herlau, 1996).

Den gensidige tilnærmelse mellem de sociale og faglige aspekter ved studielivet, som projektet fremkaldte, paralleliserer Tintos betoning af faglig og social integration, hvilket $i$ hans forskning er en gylden vej til mindskelse af studiefrafald:

"The more students are involved, academically and socially, in shared learning experiences that link them as learners with their peers, the more likely they are to become more involved in their own learning and invest the time and energy needed to learn." (Tinto, 1997: 617).

Som middel til at nå dette mål anbefaler Tinto peer learning, som faciliterede studiegrupper kan siges at være et eksempel på.

Ligeledes kan den bevidste brug af erfaringsorienterede spørgsmål ses som et fastholdelsestiltag. For eksempel har Crosling, Heagney og Thomas (2009) vist, at skal man reducere frafald, er det vigtigt at skabe forbindelse mellem curriculum og de studerendes egen livsverden. I de faciliterede studiegrupper overlades denne forbindelsesknytning ikke til tilfældighed og spontan indsigt; facilitator stiller de spørgsmål, der får de medstuderende til at eksplicitere forbindelsen.

\section{To andre versioner af studiefacilitering}

Efter det omtalte projekt (herefter kaldet version A) førte vi arbejdet videre i to mindre omfattende versioner. Vi afprøvede i efteråret 2009 en version $\mathrm{B}$, hvor alle 1 . semesterstuderende på Pædagogisk Psykologi blev tilbudt træning i studiefacilitering. Ca. en tredjedel (ca. 70) tog imod tilbuddet og blev trænet på to dages workshop i DPU's lokaler ved uddannelsens start (se evaluering og yderligere beskrivelse i Adriansen, Ravn og Tange, 2010).

Derpå fulgte version C: I efteråret 2010 gennemførte vi blot en halv dags træning, men nu af samtlige 1. semesterstuderende. Det foregik på både Pædagogisk Psykologi og søsteruddannelsen Pædagogisk Sociologi, der har et lidt mindre studenteroptag (ca. 200 årligt). Undervisningen placeredes som en almindelig undervisningsgang og fremgik af undervisningsplanen; dvs. den var ikke længere et ekstratilbud. Den faciliterede studiebar overlod vi i både version B og C til studieinstruktorerne, der arrangerede bar efter vores angivelser et par gange hvert semester. Efter version $\mathrm{B}$ og C fortsatte træning og facilitering på samme vis på begge uddannelser i efteråret 2011. 
Virkningen på studiemiljøet af de tre versioner angives i Tabel 2. AU foretog en ny studiemiljøundersøgelse i 2011, og dér udpeges fem af de ni faktorer, som vi udvalgte i 2009 (jf. Tabel 1), som de vigtigste trivselsfaktorer (AU, 2011a: 10). Derfor er det alene disse fem, vi anfører i Tabel 2. De tre første udgør tilsammen "Følelsen af at være fagligt integreret", de to sidste "God kontakt til medstuderende" (AU, 2011a: $10)$.

Tabel 2. Målinger af studiemiljøet på DPU/AU før og efter interventioner med studiefacilitering.

\begin{tabular}{|c|c|c|c|c|c|c|c|c|c|}
\hline $\begin{array}{l}\text { Nr. } \\
\text { fra } \\
\text { Tabel } \\
1\end{array}$ & $\begin{array}{l}\text { Andel stude- } \\
\text { rende, der } \\
\text { svarer "over- } \\
\text { vejende enig" } \\
\text { eller "helt } \\
\text { enig" på flg. } \\
\text { spørgsmål: }\end{array}$ & $\begin{array}{l}1 . \\
\text { Pæd. } \\
\text { Psyk. } \\
2007 \\
\\
\text { Base- } \\
\text { line }\end{array}$ & $\begin{array}{l}2 . \\
\text { Pæd. } \\
\text { Psyk. } \\
\text { Forår } \\
2009 \\
\text { Efter } \\
\text { projekt A } \\
\text { (større } \\
\text { version) }\end{array}$ & $\begin{array}{l}3 . \\
\text { Pæd. } \\
\text { Psyk. } \\
\text { Efterår } \\
2009 \\
\text { Efter } \\
\text { projekt B } \\
\text { (mindre } \\
\text { version) }\end{array}$ & $\begin{array}{l}4 . \\
\text { Pæd. } \\
\text { Psyk. } \\
2011 \\
\text { Efter } \\
\text { projek- } \\
\text { ter A, B } \\
\text { og C }\end{array}$ & $\begin{array}{l}5 . \\
\text { Pæd. } \\
\text { Soc. } \\
2007 \\
\\
\text { Base- } \\
\text { line }\end{array}$ & $\begin{array}{l}6 . \\
\text { Pæd. Soc. } \\
2011 \\
\\
\text { Efter } \\
\text { projekt C } \\
\text { (mindre } \\
\text { version) }\end{array}$ & $\begin{array}{l}7 . \\
\text { Gen. } \\
\text { Pæd. } \\
2007 \\
\\
\text { Base- } \\
\text { line }\end{array}$ & $\begin{array}{l}8 . \\
\text { Gen. } \\
\text { Pæd. } \\
2011 \\
\\
\text { Kon- } \\
\text { trol }\end{array}$ \\
\hline 8 & $\begin{array}{l}\text { Min interesse } \\
\text { i studiets } \\
\text { fagområde er } \\
\text { vokset, siden } \\
\text { jeg startede } \\
\text { på studiet }\end{array}$ & 90 & 90 & 91 & 91 & 83 & 91 & 91 & 89 \\
\hline 3 & $\begin{array}{l}\text { Studiet har } \\
\text { bidraget til, } \\
\text { at jeg føler } \\
\text { mig som del } \\
\text { af et fagligt } \\
\text { fællesskab }\end{array}$ & 48 & 70 & 57 & 66 & 42 & 66 & 61 & 64 \\
\hline 5 & $\begin{array}{l}\text { De andre } \\
\text { studerende } \\
\text { er generelt } \\
\text { imødekom- } \\
\text { mende }\end{array}$ & 80 & 91 & 79 & 83 & 77 & 85 & 81 & 89 \\
\hline 2 & $\begin{array}{l}\text { Hvordan } \\
\text { vurderer du } \\
\text { muligheder- } \\
\text { ne for social } \\
\text { kontakt med } \\
\text { medstude- } \\
\text { rende? }\end{array}$ & 29 & 74 & 49 & 37 & 35 & 45 & 35 & 28 \\
\hline 1 & $\begin{array}{l}\text { Jeg føler mig } \\
\text { som en del af } \\
\text { et større } \\
\text { fællesskab på } \\
\text { studiet }\end{array}$ & 21 & 60 & 43 & 31 & 23 & 34 & 20 & 18 \\
\hline & $\begin{array}{l}\text { Stigninger } \\
\text { (tendens) }\end{array}$ & & Store & $\begin{array}{c}\text { Mellem- } \\
\text { store }\end{array}$ & $\begin{array}{c}\text { Mel- } \\
\text { lemsto } \\
\text { re }\end{array}$ & & $\begin{array}{l}\text { Mellem- } \\
\text { store }\end{array}$ & & Ingen \\
\hline
\end{tabular}

Data i kolonne 2 er fra Ravn \& Adriansen (2009), i nr. 3 fra Adriansen, Ravn \& Tange (2010), i 1, 5 og 7 fra AU (2008b) og i 4, 6 og 8 fra AU (2011b). 
Kolonne 1 og 2 gentager kolonne 3 og 4 fra Tabel 1. Sammenligningen mellem disse to kolonner anslår virkningen af version A (idet vi minder om, at vi har med to kun delvist sammenlignelige populationer af studerende at gøre). Den virkning kan vi betegne som stor (> 20 procentpoint). Kolonne 3 er fra evalueringen af version B (foretaget efter samme metode som evalueringen af version $A)$; her er virkningen mellemstor $(\approx 10)$. I kolonne 4 anføres data fra AU's studiemiljøundersøgelse i 2011, der kan sammenlignes med den tilsvarende i 2007; også her ses en mellemstor virkning $(\approx 10)$.

De sidste fire kolonner i Tabel 2 er alle data fra AU's studiemiljøundersøgelse for to andre DPU-uddannelser: På kandidatuddannelsen i Pædagogisk Sociologi gennemførte vi projekt C (mellemstor virkning, $\approx 10$ ), mens vi på DPUs tredjestørste kandidatuddannelse, Generel Pædagogik, som ikke fik nogen faciliteringsindsats, ingen forskel ser i de fem studiemiljøvariable.

Vi konkluderer, at den intensive version A med to dages internattræning af de 17 studiefacilitatorer og med studiebar faciliteret af forfatterne havde rigtig god effekt på studiemiljøet, mens den mere begrænsede indsats i version $\mathrm{B}$ og $\mathrm{C}$ gav et mindre, men dog meget pænt resultat. Versionerne A, B og C var alle med forskellige grupper af studerende, så en tilvænningseffekt kan udelukkes. Studiebar og internatworkshops, nyhedens interesse og forfatternes uvilkårligt større nursing af de studerende har nok medvirket til version A's gode resultater. Desuden har virkningen af at gøre noget givetvis være større på de studerendes 2 . semester end på 1 . semester, hvor de studerende endnu ikke har oplevet noget dårligt studiemiljø, så den reelt forventelige virkning af en intervention med studiefacilitering er måske nærmere version B: "Mellemstore".

\section{Konklusion: Interaktion og relationer kan faciliteres frem}

Projektet og den efterfølgende institutionalisering af faciliteringen i studiegrupperne har vist, at man med fordel kan lade facilitatorer stimulere den faglige læring og det sociale samvær på en uddannelse. I den antiautoritære danske uddannelsesverden har selvorganisering og det spontane fællesskab været normen i mange år. Tanken har været, at inviterer man blot de studerende indenfor på en uddannelse eller i en studiegruppe, så sker der nok gode ting af sig selv.

Med facilitering kan man tage et skridt hinsides modsætningen mellem lederstyring og fri snak. Studiefacilitering kan have relevans for studiemiljøet ved at realisere den interaktion mellem de studerende, der ellers kun foreligger potentielt. Som DPUs studerende oplevede det: De andre er bestemt imødekommende nok, men det er svært at komme i kontakt og skabe relationer. 
Hanne Kirstine Adriansen er ph.d. i Kulturgeografi og lektor ved Institut for Uddannelse og Pædagogik ved Aarhus Universitet. Hendes forskningsfelt er facilitering af sociale læreprocesser med specielt henblik på kreativitet og innovation samt rum og læring. Hun underviser i facilitering, kreativitet og innovation samt ledelse.

Ib Ravn er lektor ved Institut for Uddannelse og Pædagogik ved Aarhus Universitet. Hans forskningsfelt er facilitering af videnprocesser på møder, ved konferencer og i netværk. Han træner periodisk ledere og medarbejdere i offentlige og private virksomheder i mødefacilitering. Hans ph.d. er fra University of Pennsylvania i Social Systems Sciences, og han har skrevet seks bøger, heraf tre om møder og konferencer.

\section{Litteratur}

Adriansen, H. K. \& Madsen, L. M. (2012). Facilitation - a novel way to improve students' well-being? Innovative Higher Education (i trykken)

Adriansen, H. K., Ravn, I, \& Tange, N. (2010). Faciliterede studiegrupper for nye studerende: Evaluering af et initiativ på DPUs kandidatuddannelse i Pædagogisk Psykologi i efteråret 2009. Working Paper, DPU, tinyurl.com/facstud-nye.

Allison, G. T. (1971). Essence of Decision. Boston: Little, Brown.

Ansoff, H. I. (1979). Strategic Management. New York: Wiley.

Berger, P, \& Luckmann, T. (1966). The Social Construction of Reality. New York: Doubleday.

Boud, D. (2001). Introduction: making the move to peer learning. I Boud. D, Cohen, R. \& Sampson, J. (red.). Peer Learning in Higher Education: Learning From \& With Each Other. Kogan Page: St. Ives.

Crosling, G., Heagney, M. \& Thomas, L. (2009). Improving student retention in higher education: Improving teaching and learning. Australian Universities Review 51(2), 9-18.

Darsø, L. \& Herlau, H. (1996). Håndbog i projektsamarbejde. København: Undervisningsministeriet.

Elsborg, S., \& Ravn, I. (2006). Lærende møder og konferencer i praksis. København: People's Press.

Gergen, K. (2005). Virkeligheder og relationer. København: Dansk Psykologisk Forlag.

Hunter, D. (2007). The Art of Facilitation. New York: Wiley.

Mead, G. H. (1934). Mind, Self and Society. Chicago: Chicago University Press.

Ravn, I. (2007): The Learning Conference. Journal of European Industrial Training, 31(3), 212-222.

Ravn, I. (2011). Facilitering: Ledelse af møder der skaber værdi og mening. København: Hans Reitzel.

Ravn, I. \& Adriansen, H. (2009). Facilitering af studiemiljø: Evaluering af et pilotprojekt på DPUs kandidatuddannelse i Pædagogisk Psykologi i foråret 2009. Working Paper, DPU, tinyurl.com/fac-stud.

Stacey, R. D. (2003). Strategic Management and Organizational Dynamics: the Challenge of Complexity. Harlow, UK: Pearson Education.

Tinto, V. (1997). Classrooms as communities: exploring the educational character of students' persistence. The Journal of Higher Education, 68(6), 599-623. 
AU (2008a). Studiemiljø 2007. Rapport nr. 1. Hovedresultater og nøgletal. Aarhus Universitet, Center for Læring og Uddannelse, v. T. K. Jensen m.fl.

AU (2008b). Studiemiljø 2007. Rapport nr. 7. Danmarks Pædagogiske Universitetsskole. Aarhus Universitet, Center for Læring og Uddannelse, v. T. K. Jensen m.fl.

AU (2011a). Studiemiljø 2011. Rapport nr. 1. Aarhus Universitet. Aarhus Universitet, Center for Læring og Uddannelse, v. T. K. Jensen m.fl.

AU (2011b). Studiemiljø 2011. Rapport nr. 5. Arts. Aarhus Universitet, Center for Læring og Uddannelse, v. T. K. Jensen m.fl. 